\title{
COMPARATIVE CHARACTERISTIC OF THE CAUSATIVE AGENTS OF CLOSTRIDIOSIS IN CATTLE
}

\author{
Pimenov Nikolai*, Doctor of Biological Sciences \\ Kolesnikova Yulia, Candidate of Biological Sciences \\ Moscow State Academy of Veterinary Medicine and Biotechnology, Moscow, Russia \\ *E-mail: pimenov-nikolai@yandex.ru
}

\begin{abstract}
Description of the etiology and comparative characteristics of the selected strains of clostridia is given in the article. The prevalence of different types of Clostridium perfringens in calves of different age groups, the etiological importance of other species of Clostridia: Cl. septicum, $\mathrm{Cl}$. sordelli, Cl. novyi are shown. Biological properties of the isolates of the causative agent of anaerobic enterotoxaemia in cattle were studied. The most pathogenic strains of $\mathrm{Cl}$. perfringens (types $A, C$ and D) were identified.
\end{abstract}

\section{KEY WORDS}

Anaerobic enterotoxaemia, clostridiosis, Clostridium: Cl. perfringens, Cl. septicum, Cl. sordellii, Cl. novyi, calves, cattle.

In cattle breeding animals must be provided with balanced feeding, exercises, the optimal conditions of maintenance and the relevant norms of microclimate parameters for life support, health, reproduction and high productivity. Even minor technological violations lead to malfunctions, diseases and death of the animals. However, intensification of animal husbandry leads to the serious changes of many physiological parameters of animal organism. Not typical diseases of the high-yielding cattle appear under the adverse conditions of maintenance and unbalanced feeding. Thus, blackleg was only one actual clostridiosis during breeding of cattle in the USSR. Diseases caused by bacteria of the genus Clostridium - Cl. perfringens, Cl. septicum, Cl. sordellii, Cl. tetani and Cl. oedematiens did not have a serious epizootic significance because they occurred in individual cases $[1,9]$.

Currently, imperfect and unbalanced feeding causes metabolic abnormalities, diseases of the digestive tract, organs, musculoskeletal system and others in cows with productivity of 8,000 liters of milk per year and up. These diseases are compounded by anaerobic infections, in particular $\mathrm{Cl}$. perfringens, $\mathrm{Cl}$. septicum, $\mathrm{Cl}$. sordellii, $\mathrm{Cl}$. novyi, $\mathrm{Cl}$. oedematiens et al. $[3,6]$.

Newborn and young heifers are most often suffered from clostridiosis immediately after calving in farms that do not monitor their physiological state during pregnancy. Organism of newborn cow does not have time or cannot be reconstructed after the changes of physiological state, and the milk yield at milking ensured not by nutrients coming from the food, but at the expense of the internal reserves of organism. The process leads to a rapid animal exhaustion, disorders of physiological homeostasis and is complicated by infectious diseases, in particular clostridiosis, which causes diseases of bowel (in this case the causative agent is $\mathrm{Cl}$. Perfringens) and muscle tissue, usually it affects pelvic limbs (causative agents are $\mathrm{Cl}$. Rerfringens, $\mathrm{Cl}$. Septicum, $\mathrm{Cl}$ sordellii and other, often - in the complex). Almost $100 \%$ of cases the disease ends with death or forced slaughter of an animal. Infections are of a fixed character and are characterized by a high mortality rate, resulting in significant economic losses for farms [1, 2, 3, 9].

Elimination of the infectious diseases with clostridial etiology is carried out in two directions: the general animal health measures and the specific prevention of diseases, which provides the insensitiveness of vaccinated animals due to the forming immunity for a sufficiently long period of time.

Today a number of products are offered including a wide range of antigens for the immunization against clostridiosis of cattle ("One Shot Ultra 8», "One Shot Ultra 10», 
«Millenium», «Multiclos», «Toxipra Plus», «Bar Vac 10»), and two Russian-made vaccines: «Clostbovac-8» (LLC «Vetbiochem») and «Antox-9» (PCF «Stavropol Biofactory»). All these preparations are intended for the vaccination of animals with 1.5 months of age and pregnant cows $[3,4,7]$.

It should be noted that for the vaccination of pregnant cows in order to create colostral immunity against the relevant to young infectious diseases of newborn calves is advisable to use complex vaccines for the prevention of the diseases of different etiology, such as escherichiosis, anaerobic enterotoxaemia, rotavirus enteritis and coronavirus infection in cattle. Currently, however, these drugs of domestic production are absent. Monovalent vaccines against the anaerobic enterotoxaemia of calves are also not presented on the market, although their use in permanently disadvantaged farms would be effective and in demand $[5,8]$. In this regard, the development of immunobiological preparation for the prevention of anaerobic infections of calves is an important issue [9].

The study of the species composition and biological properties of clostridia, which cause clinically significant diseases in cattle and selection of the most promising strains to create an experimental vaccine against clostridiosis, was the goal of this work.

The following tasks were set to achieve the goal:

- Conduct a bacteriological examination of the samples of mortem material from dead and slaughtered animals with signs of anaerobic etiology diseases, allocate isolates and identify them to species;

- Study the biological properties of the causative agents of clostridiosis. Compare their virulent and toxigenic properties;

- Describe and certify strains of clostridia.

\section{MATHERIALS AND METHODS OF RESEARCH}

To identify the causative agents of clostridiosis the study of pathological material was conducted according to the conventional methods of the laboratory diagnostics of clostridiosis. Sections of the small intestine with the content, samples of diseased muscle tissue, pieces of the heart, liver, kidney and spleen were collected for bacteriological investigations. The material was plated on Kitt-Tarozzi medium, Schaedler agar with the addition of $10 \%$ sheep blood, as well as on beef extract agar (BEA), meat-peptone broth (MPB), Sabouraud agar. Cultures were incubated in anaerobic jars at $37^{\circ} \mathrm{C}$ using the gas generating bags. Obtained pure cultures of clostridia isolates were typed by the enzymatic properties using a set of "RapIDANAll», designed to identify the most clinically relevant species of anaerobic gram-positive bacteria [7]. Obtained isolates of $\mathrm{Cl}$. perfringens were additionally identified up to the type by neutralization reaction with antitoxic serums.

Determination of pathogenicity and toxigenicity of isolates was performed by the experimental infection of laboratory animals, for that purpose chinchilla rabbits weighing 2.5 $\pm 0.54 \mathrm{~kg}$, guinea pigs weighing $250.0 \pm 4.32 \mathrm{~g}$ and white mice weighing $17.0 \pm 2.64 \mathrm{~g}$ were used.

Totally we have performed bacteriological examination of 276 samples from 46 heads of cattle: 27 heifers and 19 heads of the calves of various ages.

\section{RESULTS OF STUDY}

The material for the research was obtained from eleven regions of the Russian Federation: Belgorod, Irkutsk, Kirov, Kursk, Moscow, Nizhny Novgorod, Samara, Saratov, Tver, Chelyabinsk regions and the Republic of Mordovia. Samples of material were collected from animals with characteristic clinical signs and pathological changes: intoxication, diarrhea with signs of dehydration, subcutaneous infiltration in the back, abdomen, limbs with crepitation of tissues, gangrenous lesions of organs and tissues, and others.

Exudate in the abdominal and thoracic cavities, swelling and hemorrhagic inflammation of the small intestine, kidney softening were detected at autopsy of dead animals, which died with the signs of enterotoxaemia. Petechial hemorrhages were presented on the surfaces of 
parenchymal organs. Meltdown tissues, the presence of exudate, gas bubbles, peculiar smell, in some animals - coated with capsule limited tissue sections of dark red or cherry color with an oily texture, ranging in size from 7 to $15 \mathrm{~cm}$ in diameter were observed in lesions of muscles.

Samples of material were examined microscopically by viewing smears stained by Gram after selection and delivery to the laboratory. Sowing material on the pre-reduced KittTarozzi medium, Schaedler blood agar, BEA, MPB, Sabouraud agar was performed at presence in the smears of large gram-positive rods with size $4 \ldots 8 \times 0.6 \ldots 1.5 \mu \mathrm{m}$.

Cultures grown in anaerobic jars for $24-48 \mathrm{~h}$ at $37^{\circ} \mathrm{C}$ were used for identification of microorganisms. Specific to clostridia colonies were subcultured into 2 tubes on slant blood agar, one of them was cultured in anaerobic, and the other - under aerobic conditions (control). After 24-48 hours, smears from the culture were prepared and stained by Gram in the presence of microflora growth on agar, cultivated in anaerobic jars, and absence growth in the control. Further studies were performed at the detection of gram-positive rods with morphology characteristic for clostridia, which are not contaminated with extraneous microflora.

Identification of microorganisms was carried with the set of "RapIDANAll», for which purpose bacterial suspension was prepared with a concentration of 3 units on McFarland. The resulting suspension was uniformly distributed in the wells and cultured in a thermostat at $37^{\circ} \mathrm{C}$ for 6 hours. Further reagents «RapID ANAIl Reagent» and «RapID Spot Indole» were added to the wells. Analysis of results was performed for 2 minutes, after which the results were added to the computer program and confirmation of the identification of microorganism species was obtained.

Typification of the isolates of $\mathrm{Cl}$. perfringens was carried out by setting neutralization reaction using commercial antitoxic serums to the various types of $\mathrm{Cl}$. perfringens. Results obtained during the studies are presented in Table 1.

Table 1 - Species of Clostridium isolates, which were allocated from pathological material of cattle

\begin{tabular}{|l|l|l|l|l|l|l|l|}
\hline \multirow{2}{*}{$№$} & \multirow{2}{*}{ Animals, age } & \multicolumn{2}{l|}{ Cl. perfringens } & Cl. & $\begin{array}{l}\text { Cl. } \\
\text { septicum }\end{array}$ & $\begin{array}{l}\text { Cl. } \\
\text { sordellii }\end{array}$ & novyi \\
\cline { 3 - 7 } & & type A & type C & type D & - & - & 1 \\
\hline 1 & Calves (1-10 days) & 5 & 1 & - & - & - & 1 \\
\hline 2 & Calves (10-30 days) & - & 3 & 1 & - & - & 2 \\
\hline 3 & Young animals (1-12 months) & - & 3 & - & - & 2 & 3 \\
\hline 4 & Cows & 1 & 3 & 1 & 13 & 6 & 7 \\
\hline 5 & Total & 6 & 10 & 2 & 13 & 8 & 7 \\
\hline
\end{tabular}

Presented in Table 1 data show that from the animals $\mathrm{Cl}$. septicum were isolated most frequently - in 13 cases, Cl. rerfringens type C - 10, Cl. sordellii - 8, Cl. novyi - 7, Cl. rerfringens type A - 6 and the $D$ type - only in 2 cases.

Infection of guinea pigs and rabbits by diurnal, actively growing cultures of clostridia intramuscularly in a volume of $0.5-1.0 \mathrm{ml}$ suspension $(500 \mathrm{mln}$ of microbial cells on the optical turbidity standard) was carried for study the virulence of isolates. Strains of clostridia possessing virulent properties caused the death of animals within 24-72 hours. During these studies we have found that from the number of allocated isolates $(n=46) 25$ were virulent for laboratory animals.

Inspection showed that the most virulent for laboratory animals were isolates of $\mathrm{Cl}$. septicum, $\mathrm{Cl}$. sordellii, Cl. rerfringens types $\mathrm{C}$ and $\mathrm{A}$, somewhat less $\mathrm{Cl}$. rerfringens type $\mathrm{D}$.

All 25 cultures of clostridia, which caused the death of laboratory animals, were used to test toxicity. To obtain culture liquid with toxin content, isolates were grown on the already mentioned scheme and then they were centrifuged to pellet the cells and filtered through sterilizing filters. The resulting liquid was intravenously administered to white mice weighing 16-18 g using two mice for each isolate. Cultures that caused death of white mice within 24 hours were recognized as toxigenic. As a result of these experiments, we found that in a varying degree all selected cultures of $\mathrm{Cl}$. rerfringens type $\mathrm{C}$ were toxigenic, slightly less - $\mathrm{Cl}$. 
rerfringens types $\mathrm{A}$ and $\mathrm{D}$. One isolate of $\mathrm{Cl}$. sordellii and one of $\mathrm{Cl}$. novyi were also toxigenic, among the isolates of $\mathrm{Cl}$. septicum toxigenic cultures have not been identified.

Conducted researches have allowed to select for further work eight most pathogenic and toxigenic strains of $\mathrm{Cl}$. septicum, $\mathrm{Cl}$. sordellii, $\mathrm{Cl}$. perfringens types $\mathrm{A}, \mathrm{C}, \mathrm{D}, \mathrm{Cl}$. novyi, which can be used for vaccine production. The strains have been certified, their depositing as production strains is preparing.

\section{DISCUSSION OF RESULTS}

According to the obtained results, clostridiosis is widespread in the livestock farms of the various subjects of the Russian Federation, so the problem of effective struggle against them in cattle breeding is actual. In this regard, we were tasked to distinguish from pathological material from the fallen and slaughtered animals the causative agents of anaerobic infections - clostridiosis; to study their biological properties, virulence and toxigenicity for the purpose to select them for depositing as the production strains.

Study of 276 samples of pathological material from 46 corpses of the cattle of different age groups with the characteristic clinical, pathological and anatomical signs was conducted during the work. As a result of studies 46 isolates of clostridia were allocated, 18 of which belong to $\mathrm{Cl}$. rerfringens that is $39 \%$. Meanwhile type A dominated in the etiological structure of the anaerobic enterotoxaemia of calves, type $C$ was prevalent in young animals of older age and type $D$ - in cows. The obtained results are not fully consistent with the published data:

- Spiridonov G.N. and coauthors, who in 2010-2013 conducted a study in the Republic of Tatarstan, in which they allocated $\mathrm{Cl}$. perfringens type $\mathrm{D}$ from the calves in 7 cases and type $C$ - only in one. But the data on the predominant serotype A (15 cases) are completely consistent with the results of our studies [8]. Unfortunately, in the article of Spiridonov G.N. and coauthors the exact age of the calves is unknown, and, perhaps, our results complement the data of Spiridonov and actualize the problem of anaerobic enterotoxaemia in calves caused by $\mathrm{Cl}$. perfringens of three serotypes: A, D, C.

- In the studies of Moskalyova N.V., conducted in the farms of the Republic of Belarus in 1989-1998, it is noted that most common type of Cl. perfringens is type A (40.5\%), followed by type D - $35,1 \%$ of cases, the share of $C$ type accounts for only $24.3 \%$ of the obtained cultures [5].

Clostridia isolates, allocated by us, had a morphological, tinctorial and enzymatic properties characteristic for family. Further studies was interesting for us in identifying the most virulent isolates, assuming their high immunogenic properties, for further research on the development of vaccine against anaerobic enterotoxaemia of cattle. It was found that the most virulent were $\mathrm{Cl}$. septicum, $\mathrm{Cl}$. sordellii, $\mathrm{Cl}$. novyi, $\mathrm{Cl}$. perfringens type $\mathrm{C}$. Isolates of $\mathrm{Cl}$. perfringens type $\mathrm{C}$ and $\mathrm{Cl}$. perfringens type $\mathrm{A}$ have toxigenic properties, less toxic - $\mathrm{Cl}$. perfringens type $\mathrm{D}$.

These studies made it possible to select and to certify eight strains that will be used as the production strains in the manufacture of the series of experimental vaccines against anaerobic enterotoxaemia of calves.

\section{CONCLUSION}

Clostridiosis is widely distributed on the territory of the Russian Federation, whereas it is characterized by the stationarity and high mortality.

As a result of studies 46 isolates of clostridia were allocated from 276 samples of pathological material from 46 corpses of the cattle of different age groups from 11 regions of the Russian Federation, 18 of which belong to $\mathrm{Cl}$. rerfringens that is $39 \%$.

$\mathrm{Cl}$. perfringens types A, C, D are the most important causative agents in the etiology of the anaerobic enterotoxaemia of cattle. Meanwhile type A dominated in the newborn calves, type $C$ was prevalent in young animals of older age and type $D$ - in adult cattle. 
Eight strains of clostridia with highest virulent and toxigenic properties: $\mathrm{Cl}$. septicum, $\mathrm{Cl}$. sordellii, Cl. perfringens types A, C, D, Cl. Novyi, which can be used for vaccine production were certified.

\section{REFERENCES}

1. Kazimir A.N., 1997. Epizootologiya, etiologiya, fagoterapiya i spetsificheskaya profilaktika anaerobnoy enterotoksemii telyat $v$ khozyaystvakh Ul'yanovskoy oblasti [Epizootology, Etiology, Phage Therapy and Specific Prophylaxis of Anaerobic Enterotoxaemia of Calves in the Farms of the Ulyanovsk Region] (PhD Thesis), Kazan.

2. Kapustin A.V., Motorygin A.V., Bukova N.K., 2013. Vidovoy sostav klostridiy krupnogo rogatogo skota [The Species Composition of Clostridia of Cattle]. Vestnik Veterinarii, no 64, pp. 71-73.

3. Kolesnikova Y.N., Pimenov N.V., Kapustin A.V., 2016. Etiologiya anaerobnykh infektsiy u krupnogo rogatogo skota i sravnitel'naya kharakteristika vydelennykh shtammov klostridiy [The Etiology of Anaerobic Infections in Cattle and Comparative Characteristics of the Isolated Strains of Clostridia]. RJOAS, no 8 (56), pp. 39-48.

4. Kurlovich D.V., Karpovich V.K., Moskaleva N.V., 2013. Razrabotka i aprobatsiya vaktsiny assotsiirovannoy protiv kolibakterioza i anaerobnoy enterotoksemii telyat [Development and Testing of an Associated Vaccine against Colibacillosis and Anaerobic Enterotoxaemia of Calves]. Biotekhnologiya: real'nost' i perspektivy $v$ sel'skom khozyaystve [Biotechnology: Reality and Perspectives in Agriculture], pp. $108-113$.

5. Moskaleva N.V., 2001. Diagnostika i profilaktika anaerobnoy enterotoksemii telyat, obuslovlennoy enterotoksinom $\mathrm{Cl}$. perfringens tipa A [Diagnosis and Prevention of Anaerobic Enterotoxaemia of Calves Caused by Enterotoxin Cl. Perfringens Type A] (PhD Thesis), Minsk.

6. Nesterov I.A., 2011. Epizootologicheskiy analiz faktorov patogennosti vozbuditelya perfringeoza zhivotnykh [Epizootological Analysis of the Pathogenicity Factors of the Causative Agents of Anaerobic Enterotoxaemia of Animals]. Vestnik Veterinarii, no 2. pp. $23-27$.

7. Spiridonov A.G., 2013. Razrabotka i otsenka effektivnosti vaktsiny assotsiirovannoy protiv anaerobnoy enterotoksemii i esherikhioznoy diarei telyat [Development and Evaluation of Associated Vaccine Efficacy against Anaerobic Enterotoxaemia and Escherichiosis Diarrhea of Calves] (PhD Thesis), Kazan.

8. Spiridonov G.N., Makhmutov A.F., Spiridonov A.G., Nasretdinov D.D., 2013. Anaerobnaya enterotoksemiya i esherikhioznaya diareya telyat: etiologiya, lechenie i spetsificheskaya profilaktika [Anaerobic Enterotoxemia and Escherichiosis Diarrhea of Calves: Etiology, Treatment and Specific Prevention]. Biotekhnologiya: real'nost' i perspektivy $\mathrm{V}$ sel'skom khozyaystve [Biotechnology: Reality and Perspectives in Agriculture], pp. $123-125$.

9. Pimenov N.V., Kolesnikova Y.N., Laishevtsev A.I., Mohammad Ali Shariati, Glinushkin A., Goncharov A., 2016. Etiology and clinic-morphological manifestation of anaerobic enterotoxaemia of young cattle. International Journal of Research in Ayurveda \& Pharmacy, no 7 (2), pp. $228-231$. 